\title{
Confronting the Costs of its Past Success: Revisiting Taiwan's Post- authoritarian Political and Economic Development
}

\author{
Cal Clark* \\ Alexander C. $\operatorname{Tan}^{\dagger}$ \\ $\mathbf{1}$ Karl Ho ${ }^{\ddagger}$
}

The evolution of Taiwan's political economy seems paradoxical. From the 1960s to 1980s, Taiwan went through economic transformations that have been called an "economic miracle." This was followed by a successful democratic transition from the late 1980s to mid-1990s that might be considered a "political miracle." In the early 1990s, Taiwan could be regarded as a success story and a model for developing nations. Yet, Taiwan was soon to "enter troubled waters" marked by growing conflict and threat from China (PRC), fears about the "hollowing out" of its previously vaunted economy, and vicious polarization and gridlock in its domestic politics. We argue that many of the challenges facing Taiwan derive from unanticipated and unintended costs of its previous successes. In particular, what worked to promote successful economic and political development at one point later became counterproductive in the changed circumstances created by the country's rapid developmental trajectory. Our basic research questions, hence, are (i) whether the challenges currently facing Taiwan's political economy can be explained by the country's past pattern of development and, if so, whether these linkages appear to be connected to success or failures in Taiwan's history.

Key words: costs of success, economic development, national identity issue, polarization, political development, Taiwan

${ }^{*}$ Cal Clark is an Emeritus Professor of Political Science at Auburn University (USA). His teaching and research interests include East Asian political economy and comparative development.

${ }^{+}$Alexander C. Tan is Professor and Head of the Department of Political Science and International Relations at the University of Canterbury (New Zealand) and University Chair Professor of Political Science at National Chengchi University (Taiwan). His research focuses on comparative political economy of East Asia, parties and elections and Asian international affairs.

DOI: 10.1111 /aspp.12400

Asian Politics \& Policy-Volume 0, Number 0-Pages 1-24

(C) 2018 Policy Studies Organization. Published by Wiley Periodicals, Inc. 
‡Karl Ho is Clinical Associate Professor at the School of Political Science, Public Policy and Political Economy the University of Texas at Dallas (USA). His research focuses on political behavior in new democracies and state behavior in response to challenges to democratic development. He is also interested in the public policy and political economy of Taiwan, Hong Kong and China.

$\mathrm{T}^{\mathrm{h}}$ he evolution of the political economy of the Republic of China on Taiwan (ROC) appears rather paradoxical. From the 1960s through 1980s, the country went through a series of economic transformations that have been called an "economic miracle." This was followed by a very successful democratic transition from the late 1980s to mid-1990s that might be considered a "political miracle" in view of the country's long era of authoritarian rule. In the early 1990s, therefore, Taiwan could be considered a success story and a model for developing nations. Yet, despite these remarkable successes, Taiwan was soon to "enter troubled waters" (Clark, 2006, p. 496) marked by growing conflict with and threat from the People's Republic of China (PRC), fears about the "hollowing out" of its previously vaunted economy, and vicious polarization and gridlock in its domestic politics (Clark \& Tan, 2012, p. 92).

Our basic research questions for this paper, hence, are whether the challenges currently facing Taiwan's political economy can be explained by the country's past pattern of development and, if so, whether these linkages appear to be connected to success or failures in Taiwan's history. We find that many of the challenges facing Taiwan in the early 21st century derive from unintended effects of its previous successes that were largely unanticipated by its political leaders. In particular, what worked to promote successful economic and political development at one point later became counterproductive in the changed circumstances created by the country's rapid developmental trajectory. Ironically, therefore, Taiwan is now being confronted by the costs of success of its previous development pattern in the sense that it has developed problems that are the results of previously successful policies. That is, the very institutions and strategies that worked in the past have become counterproductive in the present. This analysis of how Taiwan is meeting the challenge of these costs of success begins with a brief summary of its economic and political "miracles." Two sections then discuss several costs of success that are predicted by major theories in political economy and examine the polarization over national identity that appears to represent a relatively new trend in developed democracies.

\section{The Taiwan Miracles}

Economically, Taiwan advanced quite rapidly from domestic light industry in the 1950s and an export boom based on these manufactured goods in the 1960s and early 1970s, to substantial industrial upgrading into the heavy and high tech industries from the late 1970s through early 1990s. Moreover, the fruits of economic development were widely shared as poverty and income inequality were reduced substantially, creating a record of "growth with equity" (Chan \& Clark, 1992 , p. 2). In the political realm, while development had clearly been retarded by the authoritarian Nationalist or Kuomintang (KMT) regime for much of the postwar era, Taiwan went through a remarkably smooth and consensual democratic 
transition between the mid-1980s and mid-1990s (Copper, 1997; Fell, 2005; Rigger, 1999; Tien, 1996). Taken together, these economic and political transformations are often called, with a good deal of justification, "miracles."

\section{The Economic Miracle}

Given the difficulties in achieving structural transformations, perhaps the most impressive facet of Taiwan's "economic miracle" has been that the country has successfully negotiated several sharp structural transformations with, in retrospect, what appears to be surprisingly few problems. In particular, three periods of major structural transformations can be discerned between 1950 and 1990. The first occurred during the 1950s when the transition from an agricultural economy was consolidated as domestic light industry developed rapidly. Second, the 1960s and early 1970s witnessed an impressive export boom for light industry and assembly products that revolutionized the economy and set off significant social changes as well. Finally, another substantial economic upgrading into the heavy and high tech industries occurred between the mid-1970s and early 1990s, accompanied by the emergence of a middle-class society.

To summarize and better understand the nature of Taiwan's development model, Figure 1 conceptualizes each of the economic transformations that occurred during this period in terms of two principal components. The first contains the major economic and political changes that defined the transformation, such as land reform in the 1950s and the explosion of the high-tech industry

\section{TRANSFORMATION FROM AGRICULTURE, $1950 \mathrm{~s}$}

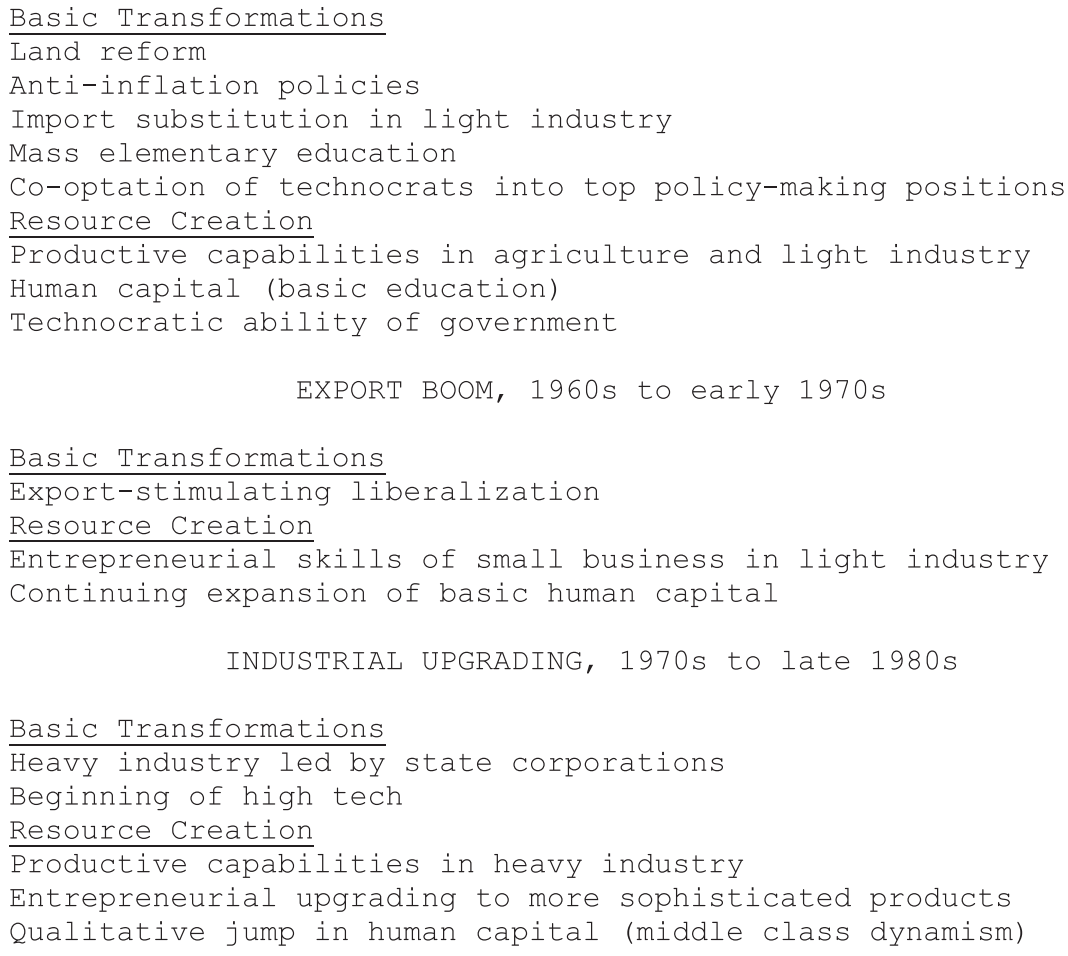

Figure 1. Structural Transformation in Taiwan's Economy. 
during the 1990s. The second then includes the major resources that were created in each period. This figure suggests the pattern or model of successful structural transformation in Taiwan. At each stage significant economic change occurred, which resulted in the creation of new major societal resources. These resources, in turn, formed the basis for the upgrading of the island's political economy in the next stage.

During the first stage in the 1950s, there were three major economic changes that brought very significant progress to the country. First, a dramatic land reform led to greatly increased productivity in agriculture, which helped alleviate poverty in the rural sector and created resources that were used to finance industrialization. Second, a stringent anti-inflation program that proved to be remarkably successful. Third, the government introduced import-substitution policies (import controls and protection) that stimulated the rapid growth of light industry. State policy also greatly enhanced the resources that could be devoted to Taiwan's development. Most importantly, mass education created human capital; the government substantially increased its economic leadership capability by bringing skilled technocrats into the top levels of the regime. The top leadership decreed the land reform and deflationary programs to prevent crises that had doomed Chiang Kai-shek on the Chinese Mainland, while import substitution was advocated by a combination of economic technocrats and American advisors (Galenson, 1979; S. P. Ho, 1978; C. Lin, 1973).

Despite the initial success of the first transformation, import substitution soon reached its inevitable high point with the saturation of the local market for light industrial goods, setting off a new challenge for Taiwan. The government, hence, was faced with choosing among three broad economic strategies: continue its current policies and hope that the economic situation did not deteriorate; attempt to implement "second-stage" import substitution in the heavy industries as was advocated by the United Nations' Economic Commission for Latin America (Prebisch, 1950); or open its economy in the hope of becoming internationally competitive in its current labor-intensive industries and promoting development through the export of these products. This strategic decision was momentous; Taiwan's "economic miracle" resulted from making the right choice, apparently. The technocrats in Taiwan's Government reached the conclusion that the third strategy was the best, and they formed an alliance with American advisors to the government in support of this drastic policy reorientation. The advocates of export-led growth, however, faced daunting opposition. First, this was certainly a risky choice; there was no guarantee that Taiwan would succeed and, indeed, at that time there were few developing countries that had taken this route. Thus, many cautious leaders feared that opening the domestic market would be disastrous because the island's light industries could not become internationally competitive. Second, the dismantling of internal economic controls challenged the vested interests of a substantial number of government and party officials, as well as the state corporations that still played a major role in the economy. Third, the military strongly advocated the development of heavy industry to help defense procurement. Despite strong opposition, the reformers were able to win the backing of President Chiang Kai-shek for moving on to a new transformation of the ROC's economy (Gold, 1986; S. P. Ho, 1987). 
There were two prongs to this strategy: attracting foreign investment for assembly operations in export processing zones and getting domestic businesses to export. The resulting export boom succeeded probably well beyond the expectations of even its proponents. Taiwan's economy boomed, promoting both rising prosperity and a tremendous drop in the level of income inequality. For example, the ratio of the total income of the richest fifth of the population to that of the poorest fifth plummeted from 20.5 in the early 1950s to 4.4 in 1973, which was low even by the standards of the developed world. The resources accumulated during the first stage formed a vital foundation for this new transformation during the 1960s and early 1970s. The technocrats conceived and implemented the major policy changes, which made this transformation possible, while its success rested on the human capital that had been developed in the workforce and business community. For instance, many managers would go to work in foreign companies, learn the business and production techniques, and then start their own businesses (Fei, Ranis, \& Kuo, 1979; Galenson, 1979; Gold, 1986; C. Lin, 1973; Wade, 1990).

Just as with import substitution, the success of Taiwan's export-led strategy contained the "seeds of its own destruction" in the sense that the island's rising prosperity and wages began to price it out of the niche of low-cost manufactured products in the world economy. Economically, the ROC responded to this new challenge with two somewhat disparate transformations. First, there was a stateled push into heavy industry, such as steel and petrochemicals, and second, the small-scale business sector began to upgrade its production techniques into such fields as advanced electronics. The former was clearly a strategic decision of the top leadership that was implemented by the economic bureaucracy. In contrast, the latter was something of a "bubble up" phenomena in which existing firms moved into more advanced production and the economic bureaucracy only responded later in the process. In the late 1980s and early 1990s, the regime had to make another set of strategic decisions as Taiwan's light industries began to move offshore. There was little controversy over the decision to not intervene in order to save them. However, President Lee Teng-hui tried, with only limited success at best, to steer them away from China (Clark \& Tan, 2012; Fields, 1995; Gold, 1986; Greene, 2008; C. Kuo, 1995; Wade, 1990). Considerable change occurred in the social realm as well with the emergence of a strong middle class (T. Cheng, 1990; H. M. Hsiao, 1991). All these trends represented an upgrading of Taiwan's economic and social capabilities.

\section{The Political Miracle}

The authoritarian government that was imposed on Taiwan after World War II by the Kuomintang (KMT) was structured around the ROC's 1947 Constitution, which on paper should have created a democracy. Unfortunately, the Constitution's liberal edifice was undercut by several important factors. First, the Constitution contained an "emergency clause" that could restrict or override constitutional provisions, which was invoked in 1948 due to the Chinese Civil War to create martial law. Second, the major "national-level" elective bodies, most importantly the Legislative Yuan (parliament) and National Assembly (that elected the President and amended the Constitution) were chosen in nationwide elections in China and Taiwan in 1947 and 1948, respectively. Once 
they evacuated to Taiwan, the Kuomintang refused to restructure these bodies, claiming that to do so would be incompatible with its claim to be the legitimate government of all China (including Taiwan). Third, the KMT also benefitted from the prohibition on the founding of new political parties, although opposition candidates could run as Independents. Clearly, Taiwan was not a democracy because Kuomintang rule was guaranteed by law (T. Ch'ien, 1950; Clough, 1978; Gold, 1986; Winckler, 1984).

The nature of authoritarian rule in Taiwan, furthermore, created a bitter legacy of ethnic hostility and tensions reverberating in the nation's politics even today. Since the evacuation of the Chiang Kai-shek regime to Taiwan in 1949 at the end of the Chinese Civil War, the island has suffered from a clear ethnic cleavage between the Mainlanders who came with Chiang (about 15\% of the population) and the longtime residents of Taiwan or Islanders, almost all of whom were ethnically Han Chinese. The Mainlanders dominated the government and imposed a harsh and repressive rule termed the "White Terror" (Clough, 1978; Mendel, 1970).

The first four decades of KMT rule witnessed a gradual transition from "hard 2 authoritarianism" to "soft authoritarianism" (Winckler, 1984, p. XX) then, in the middle of the 1980s, Taiwan set off on a rapid and bloodless democratic transition. As summarized in Figure 2, Taiwan's democratization can be conceptualized as a process that went through two basic stages: (i) Removing authoritarian institutions; and (ii) exercising popular sovereignty.

Looking at the key events in this evolution, what is striking is that they seem to have resulted not from a conflictual showdown between different political forces, but from the emergence of a wide-sweeping consensus across the political spectrum on what should be the ROC's next political steps in attaining

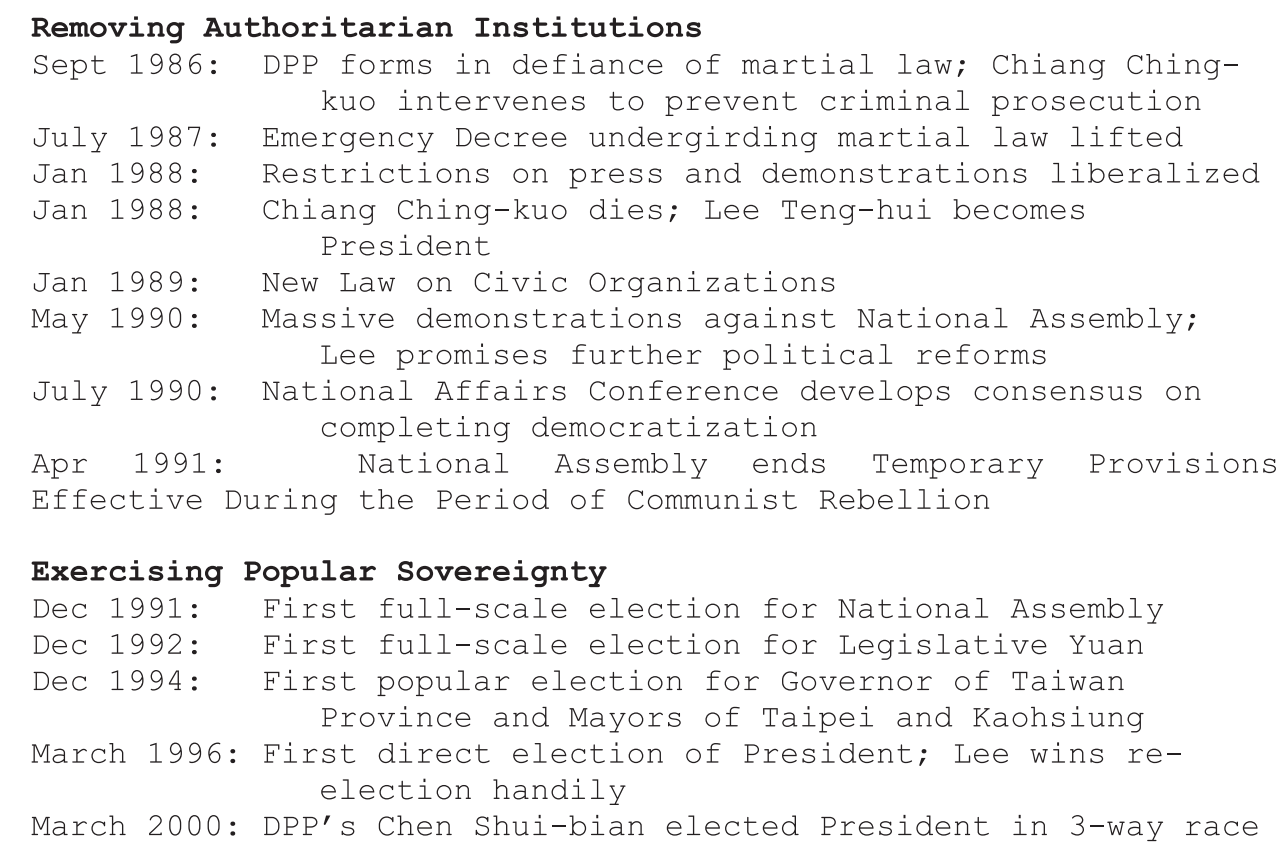

Figure 2. Major Events in Taiwan's Democratic Transition. 
democracy. In particular, two agreements or "pacts" among the leading political parties and factions helped push forward the processes of political liberalization, in line with general theories that such pacts are the key to most democratic transitions during the "third wave" of democratization (Casper \& Taylor, 1996; Huntington, 1991; O'Donnell, Schmitter, \& Whitehead, 1986).

Taiwan's democratic transition was set off in 1986 when President Chiang Chingkuo (son of Chiang Kai-shek) evidently resolved to push the ruling Kuomintang Party to accept democratization, while the opposition, called the tangwai decided to challenge the martial law restrictions on the ROC's Constitution preventing democratic practices-the ban on organizing new political parties, in particular. After the initial negotiations failed, the tangwai leaders seemingly threw down the gauntlet on the regime when they declared the formation of the Democratic Progressive Party (DPP), to which the Ministry of Justice responded by filing charges against the DPP for violating martial law restrictions. President Chiang defused the crisis, however, by announcing that martial law would be ended and new political parties could be formed as long as they supported the Constitution and renounced both communism and Taiwan Independence. Thus, there appeared to be a tacit or an informal elite settlement or pact that Taiwan's democratization could proceed apace. As charted in Figure 2, this was followed during the late 1980s by a series of steps "removing authoritarian institutions," such as lifting martial law and loosening restrictions on the press, freedom of speech, and political demonstrations (T. Cheng, 1989; Sutter, 1988).

Change was also afoot within the Kuomintang. Chiang Ching-kuo died in January 1988 and was succeeded by Vice President Lee Teng-hui as President and, after some political infighting, as KMT Chairman as well. Lee was an Islander and a technocrat with a PhD from Cornell University. The top levels of the government and party soon became divided between Lee's Mainstream faction, which tried to implement rapid political liberalization, and the Anti-Mainstream faction, which was powerful enough to hold up most major changes, creating something of a stalemate in Taiwan politics at the turn of the decade.

Almost certainly the key event that permitted the final steps of Taiwan's democratization to be taken was an "elite settlement" between the dominant faction of the ruling party and the opposition, which was worked out at the National Affairs Conference (NAC) that President Lee called in the summer of 1990 in response to massive student demonstrations. The NAC brought together representatives from diverse parts of the country's political spectrum in an unprecedented forum that created the consensus necessary to break the gridlock over issues holding back full democratization; in particular, the continuance in office of the "senior legislators" elected on the Chinese Mainland in the late 1940s. Much to the surprise of many observers, if not most, the NAC turned out to be quite a success. The debate was spirited but serious, unlike the raucous battles in many of the island's legislative arenas, and the Conference produced a consensus on how to move political reform in Taiwan forward, which soon turned into official policy and constitutional change (Higley, Huang, \& Lin, 1998; Hood, 1997; J. Wu, 1995; Moody, 1992; Wachman, 1994).

The first half of the 1990s then witnessed the completion of Taiwan's democratic transition through the expansion of "exercising popular sovereignty" (see Figure 2) as the first direct elections were held for the National Assembly in 1991, 
the Legislative Yuan in 1992, the Provincial Governor and Mayors of Taipei and Kaohsiung in 1994, and the ROC President in 1996. Even more dramatically, the DPP's Chen Shui-bian won the 2000 Presidential election in a three-way contest that resulted in the loser for the KMT nomination running as an Independent (Clark \& Tan, 2012; Rigger, 1999). Finally, democracy had arrived!

\section{The Costs of Success Facing Taiwan}

Many of the growing economic and political problems that Taiwan has faced since the mid-1990s can be considered "costs of success" because they stemmed from previous widely recognized achievements. Although they may well have not been anticipated by the country's political leaders, these challenges should not have been unexpected by scholars because two prominent theories suggest such problems are likely to arise. The first argues that as nations climb up the development ladder, they will almost inevitably reach a stage of economic maturity in which growth and improvement of social conditions slow down. The other argues that democracy and political stability, which are almost universally desired goals, can lead to some undesirable consequences.

\section{Theoretical Models}

In general, economic development follows a sequence from agriculture through light industry (textiles and shoes), through heavy industry (steel and automobiles), and through high tech industry (advanced electronics and biotechnology) to a postindustrial service-based economy; productivity and growth almost inevitably decline in a postindustrial economy because increasing them is much easier in manufacturing than in services (Kuznets, 1976; Rostow, 1960). The theory of the international product cycle explains how each of these industries, in turn, spreads like a wave through the developed world and, after World War II, many developing nations. In essence, the international product cycle refers to the life cycle of a particular good or product. Generally, new products are developed and produced in the most advanced industrial nations because they involve the latest (and most expensive) technologies, are produced by very capital-intensive processes, and require highly skilled production workers. Over time the production of the item, however, becomes more standardized and labor intensive. Consequently, as an industry matures the product cycle works to diffuse its production to countries that are not so technologically advanced but have lower labor costs and standards of living (Gilpin, 1987; Vernon, 1966).

In the political sphere, two distinct theories imply that political development may face unintended consequences similar to those associated with economic development previously noted. First, Mancur Olson's (1982) theory of The Rise and Decline of Nations argued that political stability, which is generally seen as a prerequisite for economic development, can become dysfunctional over time because it is associated with the rise of powerful interest groups or "distributional coalitions" who use their political clout to distort the economy in the pursuit of their own vested interests. Second, Samuel Huntington (1968) postulated that democratization, which is usually viewed as the centerpiece of political development, may overwhelm newly democratic governments in the developing world with more popular demands than their weak institutions can handle. 


\section{Taiwan's Economic Costs of Success}

In terms of overall growth, Taiwan definitely conforms to the general pattern of economic maturity bringing lower growth rates. For example, during the 1990s Taiwan averaged $6.6 \%$ annual growth compared to $9.3 \%$ during the industrial upgrading of the 1970s and 1980s; the first decade of the 21st century was marked by somewhat lower growth $(4.8 \%)$ between the recessions at its beginning and end, which dropped even lower to 2.3\% for 2011-2016 (National Development Council [NDC], 2016, p. 8). Furthermore, beyond these raw numbers, the people of Taiwan were clearly far from satisfied with their country's economic performance as both the Chen Shui-bian (2000-2008) and Ma Yingjeou (2008-2016) administrations received widespread harsh criticism for their economic policies (Clark \& Tan, 2012; Copper, 2016).

Figure 3 sketches a model of Taiwan's period of Economic Maturation. Unlike the first three periods of the "economic miracle" described above, when the state created a conducive environment for the country's entrepreneurial businesses, these economic dynamics are decidedly contradictory, to say the least. On the one hand, Taiwan had considerable success in upgrading into some high tech industries, such as computers and semiconductors. On the other, the loss of basic industries offshore, especially to China, undercut the ability of Taiwan's vaunted small and medium enterprises to stay competitive; and, more recently, some problems seem to be emerging in the high tech sector. Furthermore, all these trends have combined to challenge the country's reputation for "growth with equity."

Taiwan developed an internationally competitive high technology industry in a relatively short time. The centerpiece of Taiwan's high tech revolution was the electronics industry, which evolved quite rapidly from low-tech assembly to high-tech success in just a couple of decades, with the developments of each successive stage creating a foundation for the subsequent upgrading. Amsden and Chu (2003) termed these the television, calculator, and notebook computer eras. For example, Taiwan made extremely rapid progress in semiconductor

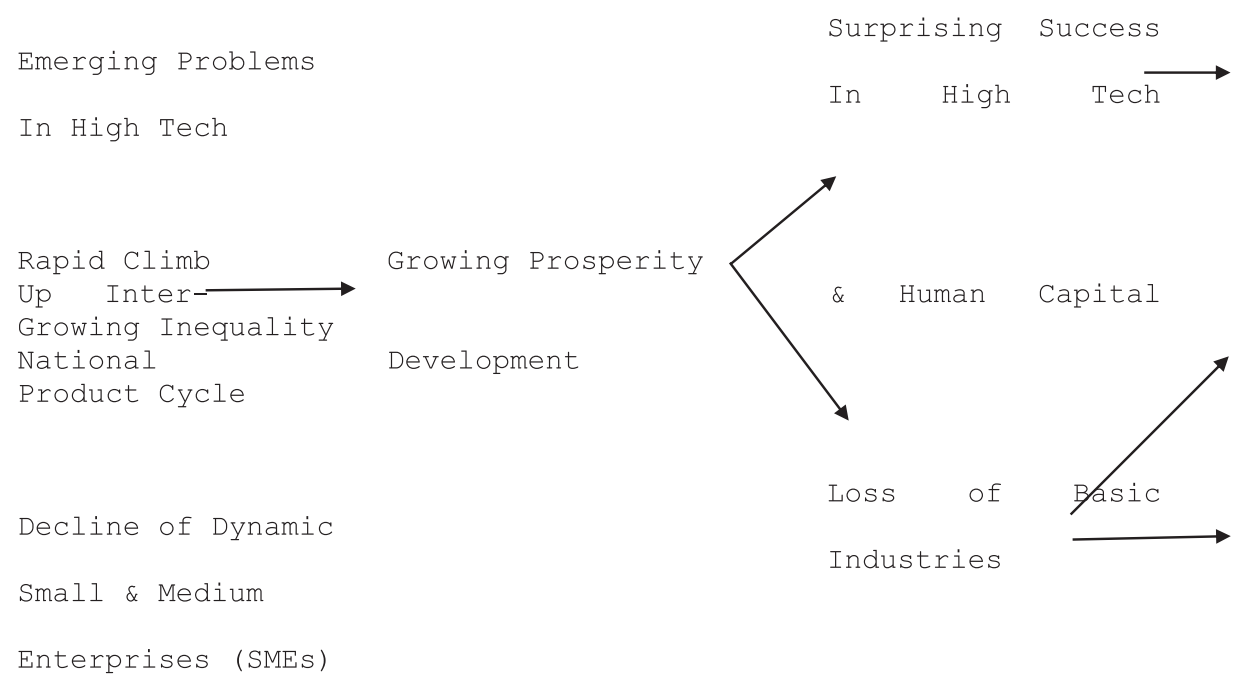

Figure 3. Dynamics of Economic Maturation in Taiwan. 
technology to reach the world frontier in the early 1990s and was fourth in the world in semiconductor production by the mid-1990s. Most strikingly, this was primarily the result of the domestic industry, which received support from the state in the forms of basic research and development (R\&D) and the development of the Science-based Industrial Park in Hsinchu (Amsden \& Chu, 2003; Berger \& Lester, 2005; Greene, 2008; Mathews \& Cho, 2000; J. Wong, 2010).

The performance of Taiwan's high tech industries is not entirely positive, however, as two significant problems have emerged in the early 21st century. First, even the country's high tech leaders, including the Taiwan Semiconductor Manufacturing Corporation, have moved considerable and increasingly sophisticated parts of their production processes to China (M. Chu, 2013; W. T. Lin, 2013; J. Wong, 2010). Second, Taiwan has been much less successful in the most advanced high tech industries, such as biotechnology, than it has been in computers and semiconductors (Wong, 2010), suggesting that Taiwanese corporations may be reaching their limits of being able to challenge global leaders at the top of the international product cycle.

The increasing loss of basic industries undercut a vital sector for Taiwan's "economic miracle." Small and medium enterprises (SMEs) had provided the dynamism for Taiwan's export boom from the 1960s through the 1980s. Their flexibility and entrepreneurship allowed them to take advantage of changing market conditions, and proved to be surprisingly capable of upgrading to the production of advanced electronics goods (Harrell, 1985; Lam \& Clark, 1994; R. Wu \& Huang, 2003). They then were able to take advantage of the growing integration across the Taiwan Strait during the 1990s by moving production to China (Naughton, 1997).

However, over the last two decades the SMEs have become increasingly squeezed between low-cost producers from developing nations and much larger and more sophisticated corporations in the developed world (R. Wu \& Huang, 2003). For example, from a high of a 70\% share of total exports in 1982, the SMEs' share of Taiwan's total exports declined to a respectable of 49\% in 1997 and then to a much lower $28 \%$ by 2006 (Small \& Medium Enterprises Administration [SMEA], 2008; R. Wu \& Huang, 2003). From this perspective, we can infer that the structure of the SMEs has become a constraint, making it difficult for them to meet the challenge of transforming themselves into knowledge-based industries.

Finally, both strands of Taiwan's economic maturation have combined to put its record "growth with equity" (Greenhalgh, 1988; S. Kuo, Ranis, \& Fei, 1981) at risk. The earlier decline of agriculture and the offshore exodus of its labor-intensive industries that began to accelerate in the late 1980s hit the poorest and least skilled segments of the population, who had always faced marginalization in Taiwan (Gates, 1987), especially hard. For its part, the successful upgrading into high-tech industries created jobs for the highly skilled but did not help those at the bottom of the income distribution that much. Consequently, the ratio of the income of the richest fifth of the population to that of the poorest fifth jumped dramatically from 4.5 in 1987 to 6.0 in 2008 and 6.1 in 2014 (NDC, 2016, p. 181). This was especially troubling because of Taiwan's history of very low support for social welfare policies, reflecting the Confucian tradition of family responsibility for caring for its members. The competitive push from the democratization of the early 1990s brought some increase in social support programs. By far the 
most important and spectacular was in the field of health care. Taiwan enacted universal health care in 1995, successfully resisted retrenchment in the late 1990s when its high costs became apparent, and is now widely regarded as having one of the best health care systems in the world (J. Wong, 2004). Still, social welfare support remains fairly limited in Taiwan (W. I. Lin \& Chou, 2007).

\section{Taiwan's Political Costs of Success}

Taiwan's democratic transition during the late 1980s and early 1990s was certainly a momentous achievement. Democratization brought some unintended consequences or side effects, though. Three of them are summarized in Figure 4. The first two represent Olson's (1982) logic that stable political institutions allow strong vested interests to develop, which manipulate government to promote their own wellbeing. One of these effects was the growth of corruption or what the Taiwanese termed "black and gold politics" during the 1990s; the other was the marked increase in the politicization of financial policy after the East Asian Financial Crisis of 1997-1998. The third side effect is consistent with Huntington's (1968) argument that new democracies can be overwhelmed by a surge in popular demands. For Taiwan, the eruption of party polarization over the fundamental question of what the country's national identity should be in the early 21st century is consistent with the Huntington thesis, but it also deviates from it because Taiwan had already developed a strong and seemingly effective government. This part of the paper discusses the first two issues, while the national identity question is discussed in more detail in the next section.

During the 1990s, political corruption became a major problem in Taiwan. This came to be called "black and gold politics"-black signifying gangsters and gold, rich businessmen. Under the KMT authoritarian regime, corruption and crime had remained fairly limited at what might be termed "first world" rather than "third world" levels. Democratization unfortunately unleashed burgeoning corruption as the declining powers of the police state made illegal activities, including political corruption, much safer.

The key stimulus, however, probably came from several unfortunate side effects that democratization itself had on the political processes. First, politics and campaigning became extremely expensive, forcing politicians to become dependent upon contributions from well-heeled business people and even gangsters. Second, the growing power of legislatures gave small groups of politicians the power to bestow favors, such as government contracts. For example, complaints were raised that legislators set up their own companies and used their new

Figure 4. Side Effects of Taiwan' Democratization. 
"power of the purse" to influence bidding on government contracts, as well as using connections with organized crime to intimidate legitimate competitors from bidding (C. Chang, 1996; Y. Chu, 1994). Third, Taiwan began a huge program of infrastructure expansion in the early 1990s, which created lucrative opportunities for those with political connections. Fourth, when Lee Teng-hui and his young Turks challenged the KMT old guard, they turned to the rich businesspeople and local patronage-oriented political factions for support, as a counterweight to the bureaucratic power wielded by their conservative rivals in the party and government. In addition, the Kuomintang ran a wide variety of businesses; many of them shared in the bonanza of rapid economic development, giving the party large amounts of Taiwan's version of political "soft money" (Bosco, 1994; M. Chen, 1996). Finally, Taiwan's dynamic economy produced substantial resources to grease the wheels of political corruption in general.

The growing politicization of the financial industry represents a "cost of success" that is associated both with Taiwan's rapid industrialization and its democratization. The strong contribution of financial chaos and collapse to the KMT's loss in the Chinese Civil War in the late 1940s led the regime to control the industry after moving to Taiwan, and to mandate fairly conservative financial practices. For several decades, this system workedwell as the formal financial system primarily funded large-scale investments (both public and private), while the informal "curb-market" proved sufficient for small enterprises (Clark, 1997; Fields, 1995). Still, Taiwan's financial institutions did become more open cumulatively. The democratization of the 1990s increasingly brought political pressures to bear on the system with not altogether positive consequences; in particular, the growing politicization of the financial industry (A. Tan, 2008; A. Tan, 2009).

\section{Political Polarization in the Early 21st Century}

Taiwan's politics after the turn of the century were marked by escalating polarization of party politics over the national identity issue of whether the country should be Chinese or Taiwanese (Makeham \& Hsiau, 2005; Wachman, 1994), which made the new democracy's politics vicious and, in the view of many, increasingly dysfunctional (Clark \& Tan, 2012; Fell, 2005, 2012 ). This polarization has often been attributed to the consequences of democratization, which made growing ethnic conflict between Mainlanders and Islanders almost inevitable once authoritarian controls were removed.

\section{Theoretical Model}

The ideological conflict in democracies from the late 19th century through the middle of the 20th century was generally based on social class. With the diminishment of class cleavages in the postwar era, there were predictions of "the end of ideology" (Bell, 1960), which presumably would reduce political polarization. Yet, by the late 20th century, there was a rise in what David Leege and his colleagues (2002) have termed "cultural issues," which directly reflect the identities of and allegiances to competing social groups. Some of these issues, including abortion, involve intense moral questions and, as a consequence, lead to polarization between camps of extremist supporters and opponents. Beyond such effects, these cultural issues also involve how groups and communities define themselves and view opposing groups who threaten their most cherished 
and fundamental values. This makes such issues very emotional and hard to compromise because they are seen as major threats to the groups and individuals in question.

National identity in Taiwan would seem to have a strong potential to create such a "cultural" divide. It involves fundamental ties to communities that are widely seen as incompatible and hostile; much of the debate on the issue in the early 21st century followed the pattern postulated by Leege and his associates (2002). Yet, as we shall see, while there is some validity to this perspective, the reality is more complex and indeterminate.

\section{Democratization Moderated National Identity Conflicts in the 1990s}

The first caution about making a simplistic linkage between democratization and polarization over national identity in Taiwan is that the initial impact of democratization during the 1990s was to moderate the national identity cleavage. As it turned out, on the key issue of what Taiwan's status should be vis-à-vis China's; strong association with either Unification or Taiwan Independence was a loser at the polls because most citizens feared that both would threaten Taiwan's social, economic, and political stability and achievements. Consequently, Taiwan's parties, especially the two major ones, came under significant pressure to take moderate positions on national identity (Fell, 2005; J. F. Hsieh, 2002; T. Y. Wang, 2000).

This resulted in a series of events in the late 1990s that would have been considered quite remarkable just a few years earlier. First, in terms of national identity, Lee Teng-hui's concept of a "New Taiwanese" identity that was open to both Islanders and Mainlanders proved to be very popular (Brown, 2004). Second, the National Development Conference of 1996 produced a consensus among the DPP, KMT, and the pro-China New Party on the previously highly contentious issue of cross-Strait relations. Finally, this growing moderation on national identity and cross-Strait relations carried over into the extremely competitive presidential campaign of 2000. Although the three major candidates certainly criticized each other, they all really advocated the moderate position of toning down hostilities with Beijing, while strongly protecting Taiwan's sovereignty (Clark \& Tan, 2012).

\section{Both Authoritarian and Democratic Eras Stimulated Polarization}

A second complexity is that the polarization at the beginning of the 2000s appears to reflect both its authoritarian past and democratic present. As indicated in Part A at the top of Figure 5, the authoritarian era and its "white terror" bequeathed several legacies that spurred polarization on national identity. First, of course, the regime's repression created strong ethnic resentment, which still reverberate through the political system. Second, the absence of a tradition of democratic compromise undermined the ability of the officials in the newly democratic government to compromise, leading to the escalation of policy disputes.

Part B of the figure then summarizes how three political conditions at the turn of the century interacted to reverse the moderating differences among the major parties on national identity and cross-Strait relations discussed above. The first was that other issues faded in importance, leaving national identity as one of the few major issues with any traction. The second was that a change in the party system after the 2000 elections promoted more polarized parties. Finally, the 
then moved quickly to one that is based on two competing blocs or coalitions of parties. The DPP and TSU became allied in the PanGreen coalition-named for the primary color in the DPP's flag - while the KMT, PFP, and New Party formed the PanBlue bloc-named for one of the colors associated with the KMT and its symbols (Fell, 2012).

The combination of the nature of these coalitions with Taiwan's election system then created a substantial push for greater polarization on national identity. The minor parties were more radical on the divisive national identity question and pressured the major parties away from moderate stances (Copper, 2004; W. Lee, 2005). Moreover, Taiwan's election system at that time of the Single NonTransferrable Vote (SNTV) considerably magnified the pressure that the minor parties and extremists in the major parties could exert on their coalition leaders. In SNTV, each voter can cast only one vote in a large multimember electoral district. Consequently, candidates must compete against both the other members of their coalition and the candidates of the other coalition; only a fairly small percentage of the vote is necessary for victory, this encouraging radical candidates whose victories make it harder for the parties to compromise. However, the abolishment of Taiwan's SNTV system in 2004 had little discernible influence on the country's polarized politics (J. Hsieh, 2006, 2009 ; Rigger, 1999).

The incentives of the party and electoral systems were exacerbated by a change in party strategies that put more emphasis on appealing to "base constitutions" rather than the "median voter." For the Pan-Blue parties, there were two specific conditions that help explain this: first, since they were out of power they were primarily concerned with raising the spirits of their current supporters, and directed their attention to criticizing and obstructing the Chen administration rather than formulating and advocating realistic policies (A. Tan, 2014). Second, Lee Teng-hui's departure from the KMT changed the nature of the coalition leader significantly since it removed his influence and brought the return to power of many pro-China members of the Anti-Mainstream faction (Fell, 2005). In the Pan-Green bloc, Chen Shui-bian used Taiwanese nationalism as a conscious electoral strategy. Wei-chin Lee (2005) argues that an important difference between Chen's approach to "nation-building" and Lee Teng-hui's in the 1990s made this especially polarizing. Lee sought to create a Taiwanese nationalism and a nation that could encompass all residents of the country, representing what has been called "civic nationalism" (S. Shen \& Wu, 2008). Thus, Lee's concept of a "New Taiwanese" identity was open to everyone and implied that old ethnic enmities could be left in the past, creating a new approach to national identity that appeared to be widely popular across the political spectrum (Brown, 2004). In contrast, Chen Shui-bian was more concerned with appealing to specific groups, particularly the Minnan who had come to Taiwan from Fujian Province and constituted slightly over $70 \%$ of the population, in what has been called "ethnic nationalism" (S. Shen \& Wu, 2008). Consequently, the Chen approach was much more polarizing than Lee's strategy.

\section{Continuing Polarization with Shifting Pressure from National Identity}

A third caveat to the view that democratization in Taiwan stimulated a dysfunctional polarization on the question of national identity comes from public 
opinion data which suggest that the general citizenry is considerably less polarized than the elites. On Taiwan's international status of whether its ultimate goal should be Independence or Unification, the general citizenry also clearly rejects both extreme positions. Table 1 demonstrates that in the past two decades a majority of about $60 \%$ had supported the diplomatic status quo over Independence or Unification, ambiguous and even ridiculous as it may be. This strong and continuing support for the status quo in Taiwan's international status is especially striking because, as Rigger (2004) has noted, growing frustration across the political spectrum with Taiwan's lack of international status and treatment by China is very easy to discern. Rather, the dangers of the two extremes are evidently so pronounced that the not-particularly-satisfactory current situation is accepted as tolerable.

Several studies of national identity in Taiwan likewise cast doubt upon the image of a polarized electorate. Several in-depth analyses conclude that many of Taiwan's citizens possess a complex identity that includes both Taiwanese and Chinese components and are wary of extreme positions on cross-Strait relations (Brown, 2004; Rigger, 1999; Wachman, 1994). For the last two decades, public opinion surveys have asked whether people identify themselves as Chinese, Taiwanese, or a combination of both. Here the results are slightly more ambiguous than on international status. Table 2 shows that in 1992 the distribution of public opinion paralleled that on international status as just over half the population (52\%) expressed a dual identity, while Chinese identifiers slightly

Table 1. Preference for Taiwan's International Status

\begin{tabular}{llll}
\hline \hline & Independence & Status Quo & Unification \\
\hline 1994 & $14 \%$ & $61 \%$ & $25 \%$ \\
1996 & $17 \%$ & $56 \%$ & $27 \%$ \\
2000 & $18 \%$ & $59 \%$ & $23 \%$ \\
2004 & $24 \%$ & $61 \%$ & $15 \%$ \\
2008 & $26 \%$ & $63 \%$ & $11 \%$ \\
2010 & $24 \%$ & $64 \%$ & $12 \%$ \\
2016 & $28 \%$ & $58 \%$ & $14 \%$ \\
\hline \hline
\end{tabular}

Source: Election Study Center. 1994, 1996, 2000, 2004, 2008, 2010, 2016. Mucha, Taiwan: Election Study Center, National Cheng-chi University. Results from Election Polls.

Table 2. Ethnic Identification of Taiwan's Citizens

\begin{tabular}{llll}
\hline \hline & Taiwanese & Both & Chinese \\
\hline 1992 & $20 \%$ & $52 \%$ & $28 \%$ \\
1996 & $24 \%$ & $56 \%$ & $20 \%$ \\
2000 & $39 \%$ & $47 \%$ & $14 \%$ \\
2004 & $43 \%$ & $51 \%$ & $6 \%$ \\
2008 & $51 \%$ & $45 \%$ & $4 \%$ \\
2010 & $55 \%$ & $42 \%$ & $3 \%$ \\
2016 & $63 \%$ & $33 \%$ & $4 \%$ \\
\hline \hline
\end{tabular}

Source: Election Study Center. 1992, 1996, 2000, 2004, 2008, 2010, 2016. Mucha, Taiwan: Election Study Center, National Cheng-chi University. Results from Election Polls. 
outnumbered Taiwanese ones (28-20\%). Thereafter, the number of Chinese identifiers collapsed and in 2004 only a sixth of even Mainlanders considered themselves Chinese. Dual identifiers retained the majority or plurality through 2004, but by 2016 Taiwanese identifiers held nearly a two-to-one margin of 63-33\%. This clearly represents a massive shift toward Taiwanese identification (S. Y. Ho \& Liu, 2003; S. Shen \& Wu, 2008), which might suggest a pro-Independence stance. Still, the data on attitudes about Taiwan's international status that were just discussed indicate that this does not appear to be the case.

A moderate public might be expected theoretically to push a country's major parties to moderate their polarization, and this, indeed, appears to have occurred in Taiwan at the end of Chen Shui-bian's second term. In the 2008 presidential election, which pitted the DPP's Frank Hsieh against the KMT's Ma Ying-jeou, Chen initially appealed to the Green base with proposals for, first, constitutional revision then referenda that were considered quite controversial. When the DPP lost the January parliamentary elections decisively, however, Chen left the presidential campaign to the more moderate Hsieh. For his part, Ma countered DPP suspicion about his proposals to improve relations with China, especially in the economic sphere, with a pledge to adhere to "Three Noes" (No Unification, No Independence, and No War). Initially after Ma's election, there was a fierce partisan struggle over his rapprochement with China, but national identity and cross-Strait relations played only minor roles in the 2010 local elections. National identity was more pronounced in the 2012 presidential and legislative elections, but the parties were clearly less polarized than earlier in the decade. For example, Ma quickly backed off from a somewhat vague proposal for future political negotiations with China when it was poorly received by the voters. Moreover, Tsai Ing-wen, the DPP candidate, did not stridently oppose the Economic Cooperation Framework Agreement (ECFA) that Ma had negotiated with China (Copper, 2011; Rigger, 2010; H. Tien \& Tung, 2011; Y. Wu, 2011).

Despite the apparent trend toward modernization on national identity, Taiwan's politics remained strongly polarized and conflictual (Clark \& Tan, 2012; Fell, 2012). Then, in March 2014, cross-Strait relations erupted as a central issue when Ma tried to force the Cross-Strait Service Trade Agreement that had been negotiated with China through the Legislative Yuan. The student Sunflower Movement occupied the Legislative Yuan and organized massive demonstrations in protest. The massive drubbing that the KMT took in the November local elections and in the 2016 presidential and legislative elections was widely seen as an indication of growing suspicion of Ma's conciliatory policies toward Beijing (Copper, 2016; J. Hsieh, 2015).

Given this political dynamic, it is not surprising that the major debate over economic policy in Taiwan has been whether increasing economic linkages and integration with China will invigorate the country's fortunes or undercut its sovereignty and overall economic performance. The general stereotype is that the KMT has promoted and the DPP has resisted the huge increase in crossStrait economic interactions that has occurred since 1990. Yet, this has certainly not been the case. For example, there have been two growth spurts In Taiwan's exports to China. The first occurred between 1991 and 1995, despite President Lee's less than enthusiastic attitude, when China's share of Taiwan's total exports rose sharply from 10 to $17 \%$. The second occurred during the presidency 
of the pro-Independence DPP's Chen Shui-bian between 2000 and 2005 when it jumped from 16 to $28 \%$, associated with President Chen's "Active Opening" Reforms in 2001. During the administration of Ma Ying-jeou, in contrast, there was little change in China's share of Taiwan's exports, which remained about $27 \%$, despite such major cross-Strait trade agreements as the Three Links and the ECFA. This, we argue, has three important implications: First, cross-Strait trade appears to have been primarily determined by economic, not political, factors. Second, Taiwan appears to have reached a plateau in its economic relations with China. Consequently, the current debate over increasing or decreasing economic interactions with China is fairly irrelevant (Clark, Ho, \& Tan, 2017).

One image of Taiwan is that its democratization brought vicious and dysfunctional political conflict centered on the explosive national identity issue. To those who are not friends of Taiwan, such as China, therefore, polarization is viewed as a cost of success of its democratic transition. Yet, there are several reasons to question this stereotype. First, democratization led to the moderation of party cleavages on national identity in the 1990s. Second, the escalating polarization that occurred during most of the first decade of the 21st century can be traced to both democratization and legacies from the authoritarian era. Finally, even during the height of polarization, many initiatives (even those by the supposed Independence zealot Chen Shui-bian) appeared not ideological but strategic in the sense that appeals to Chinese and Taiwanese nationalism were turned on and off depending upon the political situation (Clark \& Tan, 2012; Y. Wu, 2011).

\section{Implications}

Taiwan's economic and political "miracles" have been challenged since the mid-1990s by a variety of "costs of success," as factors that were beneficial in the past began to create problems for the present. The second column in Figure 6 summarizes the six major challenges that were discussed in this paper and the third gives an empirical example of each. In the economic realm, the international bursting of the high tech bubble in 2000 marked the beginning of a definite drop in the country's real economic growth rate, from $6.3 \%$ during the $1990 \mathrm{~s}$ to 2.3\% during 2011-2016 (NDC, 2016, p. 8); the decline of the SMEs began to accelerate during the 1990s as their share of total exports plummeted from $70 \%$ in 1982 to 28\% in 2006 (SMEA, 2008; R. Wu \& Huang, 2003); and the major jump in income inequality occurred after 1985, which resulted in $61 \%$ of Taiwanese believing that inequality was severe in 2016 (Taiwan's Election \& Democratization Study, 2016, 2016).

Politically, President Chen Shui-bian's proclamation of "one country on each side of the Taiwan Strait" unleashed the period of polarization over national identity (Clark \& Tan, 2012); political interference in economic policy commenced in the late 1990s as exemplified by the mergers and acquisitions scandals of the early 21st century (A. Tan, 2008); and the burgeoning of political corruption can be traced to the early 1990s when such scandals as the support of the Hualong Conglomerate by a multiparty group of legislators became common (Chang, 1996).

The first column on the left lists the primary source or cause of a particular cost of success in terms of the three theories that were applied in this analysis: (i) The normal operation of the international product cycle, (ii) the economic distortions 


\begin{tabular}{|c|c|c|c|c|c|}
\hline Source & $\begin{array}{l}\text { Cost of } \\
\text { Success }\end{array}$ & Example & Start & Anticipated? & Possible Response \\
\hline $\begin{array}{l}\text { Product Cycle } \\
\text { Distributional } \\
\text { Coalitions }\end{array}$ & $\begin{array}{l}\text { Stagnating } \\
\text { Growth }\end{array}$ & $\begin{array}{l}\text { Real growth fell } \\
\text { from } 6.3 \% \text { in the } \\
1990 \text { s to } 2.3 \% \text { in } \\
2011-16\end{array}$ & 2000 & $\begin{array}{l}\text { Some realization that miracle } \\
\text { growth would decline but } \\
\text { substantial drop not expected }\end{array}$ & $\begin{array}{l}\text { Build upon high tech } \\
\text { capabilities and key role in } \\
\text { global supply chains }\end{array}$ \\
\hline $\begin{array}{l}\text { Product Cycle } \\
\text { Distributional } \\
\text { Coalitions }\end{array}$ & $\begin{array}{l}\text { Decline of } \\
\text { SMEs }\end{array}$ & $\begin{array}{l}\text { SMEs' share of } \\
\text { exports fell from } \\
70 \% \text { in } 1982 \text { to } 28 \% \\
\text { in } 2006\end{array}$ & $1990 \mathrm{~s}$ & $\begin{array}{l}\text { Gradually over time after } \\
1990\end{array}$ & Find new trade partners \\
\hline $\begin{array}{l}\text { Product Cycle } \\
\text { Distributional } \\
\text { Coalitions }\end{array}$ & $\begin{array}{l}\text { Growing } \\
\text { Inequality }\end{array}$ & $\begin{array}{l}61 \% \text { of Taiwanese } \\
\text { felt that inequality } \\
\text { was severe in } 2016\end{array}$ & $\begin{array}{l}1985- \\
1995\end{array}$ & Not really & $\begin{array}{lll}\text { Government policies } & \text { to } \\
\text { compensate victims } & \text { of } \\
\text { economic change } & \end{array}$ \\
\hline & POLITICAL & & & & \\
\hline $\begin{array}{l}\text { Immature } \\
\text { Institutions?? }\end{array}$ & $\begin{array}{l}\text { Polarized } \\
\text { Politics }\end{array}$ & $\begin{array}{l}\text { Chen Shui-bian's } \\
\text { "country on each } \\
\text { side" concept }\end{array}$ & 2002 & $\begin{array}{l}\text { Only by opponents of } \\
\text { democratization }\end{array}$ & $\begin{array}{l}\text { Be more responsive to general } \\
\text { public and civil society than to } \\
\text { partisan activists }\end{array}$ \\
\hline $\begin{array}{l}\text { Distributional } \\
\text { Coalitions }\end{array}$ & $\begin{array}{l}\text { Political } \\
\text { Interference } \\
\text { in Economic } \\
\text { Policy }\end{array}$ & $\begin{array}{l}\text { Scandals about } \\
\text { mergers } \quad \& \\
\text { acquisitions in early } \\
21^{\text {st }} \text { century }\end{array}$ & $\begin{array}{l}\text { Late } \\
1990 \mathrm{~s}\end{array}$ & $\begin{array}{l}\text { Only by opponents of } \\
\text { democratization }\end{array}$ & Anti-corruption reforms \\
\hline $\begin{array}{l}\text { Distributional } \\
\text { Coalitions }\end{array}$ & Corruption & $\begin{array}{l}\text { Multi-party group of } \\
\text { legislators } \\
\text { supporting Hualong } \\
\text { Conglomerate in } \\
\text { mid-1990s scandals }\end{array}$ & $\begin{array}{l}\text { Early } \\
1990 \text { s }\end{array}$ & $\begin{array}{l}\text { Only by opponents of } \\
\text { democratization }\end{array}$ & Anti-corruption reforms \\
\hline
\end{tabular}

Figure 6. Taiwan's Cost of Success.

caused by "distributional coalitions," and (iii) the ineffectiveness of weak democratic institutions. The three economic costs of success (stagnating growth, decline of SMEs, and growing inequality) were all stimulated by Taiwan's evolving position in the international product cycle, but these problems were also exacerbated by the growth of distributional coalitions that democracy brought. In the political realm, the rise of distributional coalitions made a substantial contribution to the politicizing of economic and financial policy and the burgeoning corruption in Taiwan. Weak democratic institutions provide a potential explanation for the country's polarization over national identity, but (as argued above) the empirical evidence for this is mixed at best.

The fact that all six of these phenomena can be explained by academic theories raises two important questions. The first is whether Taiwan's political leaders anticipated these challenges; the fourth column in Figure 6 summarizes the 
answers. One reason that they might not have in the economic sphere is that Taiwan was in the leading group of developing countries that had industrialized through export-led growth. Thus, while they had certainly seen the shift of labor-intensive industries out of the developed world, they might well not have anticipated that their country would reach a similar phase in the international product cycle so quickly. Even today, for example, there is debate over whether Taiwan is facing a "middle-income trap" like Malaysia ("Academic Warns Taiwan over Middle-Income Trap", 2017) of a "high income trap" like Japan (Murayama, 2017,). Regarding income inequality, while it is now widely recognized that the transformation from an industrial to a postindustrial society is accompanied by rising inequality (Organization for Economic Co-operation \& Development [OECD], 2012), there was only limited discussion of this issue in the late 1980s. Moreover, the ill effects of democratization were predicted by the conservative KMT leaders who were loath to give up power, but the vast majority of Taiwanese welcomed political reform as a major step forward.

The last column in Figure 6 contains possible policies that could mitigate these problems. To reinvigorate growth, Taiwan should try to expand its advanced manufacturing at home by taking advantage of its highly educated and skilled population and expand its role in global supply chains; and the government could actively seek to aid citizens who have suffered from the economic changes sweeping over Taiwan. Reducing polarization and gridlock would entail leaders paying more attention to the general public and civil society (?) than to party activists; effective anti-corruption drives could reduce officials' illegal activities and politicians' interference in economic activities. Finally, finding new trade partners that are still developing basic industries could provide new opportunities for Taiwan's SMEs. Almost all of these policy shifts, however, would require fundamental shifts in the country's prevailing political culture, which make them far harder to implement than to propose. Yet, the ongoing challenges that Taiwan faces should not obscure the nation's major accomplishments. Its hardwon democracy can now be considered consolidated and legitimate-certainly no mean accomplishment. For example, election results and power transitions are widely accepted; and the political repression and abuses of the authoritarian era are now unthinkable. In the economic realm Taiwan has become a fairly prosperous society, decent levels of growth have been maintained, and China has not been able to gain much leverage from the growing economic integration across the Taiwan Strait. Thus, the fact that the situation is far from bleak should remind us of the nation's half century of flexibility and success in the face of developmental challenges.

Two factors suggest that there might be some basis for creating a more faciliatory political environment in Taiwan. First, a not widely recognized characteristic of Taiwan's twin "miracles" was their inclusive nature, in the sense that broad segments of the population could take credit for them. In the economic sphere, the Mainlander-dominated government created a "conducive context" for each of the three structural transformations summarized in Figure 1. Yet, the Islander business community, especially SMEs with almost no government contacts, drove the upgrading of the economy with the entrepreneurial activities. Likewise, Taiwan's democratic transition needed both agitation from the illegal 
political opposition and later on the DPP and the efforts of reformers within the KMT regime, culminating in the elite settlement of the NAC that was widely supported in the country (Clark \& Tan, 2012). Second, a study of young voters in the 2016 election found that they had complex views about national identity that were more sophisticated than the stark and simplistic alternatives offered by the two major parties (T. Y. Wang \& Cheng, 2017). Consequently, it is conceivable that a visionary political leader or group could create a new narrative that would unite, rather than divide, Taiwan's citizens.

\section{References}

Academic warns Taiwan over middle-income trap. (2017, November 9). Taipei Times. p. 16.

Amsden, Alice H., \& Chu, Wan-Wen. (2003). Beyond late development: Taiwan's upgrading policies. Cambridge: MIT Press.

Bell, Daniel (1960). The end of ideology: on the exhaustion of political ideas in the 1950s. Glencoe, IL: Free Press.

Berger, Suzanne, \& Lester, Richard K. (Eds.) (2005). Global Taiwan: Building competitive strengths in a new international economy. Armonk, NY: M.E. Sharpe.

Bosco, Joseph. (1994). Taiwan factions: Guanxi, patronage, and the state in local politics. In Murray A. Rubinstein (Ed.), The other Taiwan, 1945 to the present (pp. 114-44). Armonk, NY: M.E. Sharpe.

Brown, Melissa J. (2004). Is Taiwan Chinese? The impact of culture, power, and migration on changing identities. Berkeley: University of California Press.

Casper, Gretchen, \& Taylor, Michelle M. (1996). Negotiating democracy: Transitions from authoritarian rule. Pittsburgh: University of Pittsburgh Press.

Ch'ien, Tuan-sheng. (1950). The government and politics of China. Cambridge: Harvard University Press.

Chan, Steve, \& Clark, Cal. (1992). Flexibility, foresight, and fortuna in Taiwan's development: Navigating between Scylla and Charybdis. London: Routledge.

Chang, Ching-hui. (1996). The limits of Statism in Taiwan: The distortions of policies ignoring small enterprise dynamism. American Asian Review, 14(2), 71-96.

Chen, Ming-tong. (1996). Local factions and elections in Taiwan's democratization. In Hung-mao Tien (Ed.), Taiwan's electoral politics and democratic transition: Riding the third wave (pp. 174-92). Armonk, NY: M.E. Sharpe.

Cheng, Tun-jen. (1989). Democratizing the Quasi-Leninist regime in Taiwan. World Politics, 41(4), $471-99$.

Cheng, Tun-jen. (1990). Political regimes and development strategies. In Gary Gereffi \& Donald L. Wyman (Eds.), Manufacturing miracles: Paths of industrialization in latin America and East Asia (pp. 139-78). Princeton: Princeton University Press.

Chu, Yun-han. (1994). The realignment of state-business relations and regime transition in Taiwan. In Andrew MacIntyre (Ed.), Business and government in industrializing East and Southeast Asia (pp. 113-141). Sydney: Allen \& Unwin.

$\mathrm{Chu}$, Monique Ming-chin. (2013). Semiconductor interconnectivity across the Taiwan Strait: A case study approach. In: Peter C. Y. Chow (Ed.), Economic integration across the Taiwan Strait: Global perspectives (pp. 197-238). Cheltenham, UK: Edward Elgar.

Clark, Cal. (1997). Taiwan's financial system: Prosperity from countervailing perversities? In Richard D. Bingham \& Edward W. Hill (Eds.), Global perspectives on economic development: Government and business finance (pp. 116-65). New Brunswick, NJ: Center for Urban Policy Research, Rutgers University.

Clark, Cal. (2006). Taiwan enters troubled waters: The elective presidencies of Lee Teng-hui and Chen Shui-bian. In Murray Rubinstein (Ed.), Taiwan: A new history (Revised ed, pp. 496-535). Armonk, NY: M.E. Sharpe.

Clark, Cal, Ho, Karl, \& Tan, Alexander C. (2017, April). Ending Taiwan's economic stagnation: The implications of the elections of presidents Tsai and Trump. Paper presented at the Conference on Triangular Relations by Decade's End, University of St. Thomas, Houston, TX.

Clark, Cal, \& Tan, Alexander C. (2012). Taiwan's political economy: Meeting challenges, pursuing progress. Boulder, CO: Lynne Rienner.

Clough, Ralph N. (1978). Island China. Cambridge: Harvard University Press.

Copper, John F. (1997). The Taiwan political miracle: Essays on political development, elections and foreign relations. New York: University Press of America. 
Copper, John F. (2004). Taiwan's 2004 Presidential and Vice Presidential Election: Democracy's consolidation or devolution? (University of Maryland Series in Contemporary Asian Studies). Baltimore: University of Maryland.

Copper, John F. (2011). Taiwan's 2011 Metropolitan City Elections: An Assessment of Taiwan's Politics and a Prediction of Future Elections (University of Maryland Series in Contemporary Asian Studies). Baltimore: University of Maryland.

Copper, John F. (2016). Taiwan's 2016 Presidential/Vice Presidential and Legislative Elections: Reflections on the Nature of Taiwan's Politics and Shifts Therein (University of Maryland Series in Contemporary Asian Studies). Baltimore: University of Maryland.

Fei, John C. H., Ranis, Gustav, \& Kuo, Shirley W. Y. (1979). Growth with equity: The Taiwan case. New York: Oxford University Press.

Fell, Dafydd. (2005). Party politics in Taiwan: Party change and the democratic evolution of Taiwan, 1991-2004. London: Routledge.

Fell, Dafydd. (2012). Government and politics in Taiwan. London: Routledge.

Fields, Karl J. (1995). Enterprise and the state in South Korea and Taiwan. Ithaca: Cornell University Press.

Galenson, Walter. (Ed.) (1979). Economic growth and structural change in Taiwan: The postwar experience of the Republic of China. Ithaca: Cornell University Press.

Gates, Hill. (1987). Chinese working-class lives: Getting by in Taiwan. Ithaca: Cornell University Press.

Gilpin, Robert. (1987). The political economy of international relations. Princeton: Princeton University Press.

Gold, Thomas B. (1986). State and society in the Taiwan miracle. Armonk, NY: M.E. Sharpe.

Greene, J. Megan. (2008). The origins of the developmental State in Taiwan: Science policy and the quest for modernization. Cambridge: Harvard University Press.

Greenhalgh, Susan. (1988). Supranational processes of income distribution. In Edwin A. Winckler \& Susan Greenhalgh (Eds.), Contending approaches to the political economy of Taiwan (pp. 67-100). Armonk, NY: M.E. Sharpe.

Harrell, Stevan. (1985). Why do the chinese work so hard? Reflections on an entrepreneurial ethic. Modern China, 11(2), 203-26.

Higley, John, Huang, Tung-yi, \& Lin, Tse-min. (1998). Elite settlements in Taiwan. Journal of Democracy, 9(2), 148-63.

Ho, Samuel P. S. (1978). Economic development in Taiwan, 1860-1970. New Haven: Yale University Press.

Ho, Samuel P. S. (1987). Economics, economic bureaucracy, and Taiwan's economic development. Pacific Affairs, 60(2), 226-47.

Ho, Szu-yin, \& Liu, I-chou. (2003). The Taiwanese/Chinese identity of the Taiwan People in the 1990s. In Wei-chin Lee \& T. Y. Wang (Eds.), Sayonara to the Lee Teng-hui Era: Politics in Taiwan, 1988-2000 (pp. 149-83). Lanham, MD: University Press of America.

Hood, Steven J. (1997). The Kuomintang and the democratization of Taiwan. Boulder, CO: Westview.

Hsiao, Hsin-huang Michael. (1991). The changing state-society relations in the ROC: Economic change, the transformation of class structure, and the rise of social movements. In Ramon $\mathrm{H}$. Myers (Ed.), Two societies in opposition: The Republic of China and the People's Republic of China after forty years (pp. 127-40). Stanford: Hoover Institution Press.

Hsieh, John Fuh-sheng. (2002). Continuity and change in Taiwan's electoral politics. In John Fuhsheng Hsieh \& David Newman (Eds.), How Asia votes (pp. 32-49). New York: Chatham House.

Hsieh, John Fuh-sheng. (2006). Institutional design for a mildly divided society. Issues $\mathcal{E}$ Studies, 42(1), 81-102.

Hsieh, John Fuh-sheng. (2009). The Origins and consequences of electoral reform in Taiwan. Issues $\mathcal{E}$ Studies, 45(2), 1-22.

Hsieh, John Fuh-sheng. (2015). Taiwan in 2014: A besieged president and political turmoil. Asian Survey, 55(1), 142-7.

Huntington, Samuel P. (1968). Political order in changing societies. New Haven: Yale University Press.

Huntington, Samuel P. (1991). The third wave: Democratization in the Late Twentieth Century. Norman: University of Oklahoma Press.

Kuo, Cheng-Tian. (1995). Global competitiveness and industrial growth in Taiwan and the Philippines. Pittsburgh: University of Pittsburgh Press.

Kuo, Shirley W. Y., Ranis, Gustav, \& Fei, John C. H. (1981). The Taiwan success story: Rapid growth with improved income distribution in the Republic of China. Boulder, CO: Westview.

Kuznets, Simon. (1976). Modern economic growth: Rate, structure and spread. New Haven: Yale University Press.

Lam, Danny, \& Clark, Cal. (1994). Beyond the developmental state: The cultural roots of 'guerrilla capitalism' in Taiwan. Governance, 7(4), 412-29. 
Lee, Wei-chin. (2005). Taiwan's cultural reconstruction movement: Identity politics and collective action since 2000. Issues \& Studies, 41(1), 1-51.

Leege, David C., Wald, Kenneth D., Krueger, Brian S., \& Mueller, Paul D. (2002). The politics of cultural differences: Social change and voter mobilization in the post-new deal period. Princeton: Princeton University Press.

Lin, Ching-yuan. (1973). Industrialization in Taiwan, 1946-1972: Trade and import substitution policies for developing countries. New York: Praeger.

Lin, Winston T. (2013). Assessing the impacts of the integration of the ICT investments of Taiwan and China upon economic growth in Taiwan. In Peter C. Y. Chow (Ed.), Economic integration across the Taiwan Strait: Global perspectives (pp. 56-80). Cheltenham, UK: Edward Elgar.

Lin, Wen-I, \& Chou, Wei-chi Grace. (2007). Globalization, regime transformation, and social policy development in Taiwan. In James Lee \& Kam-Wah Chan (Eds.), The crisis of the welfare state in East Asia (pp. 101-23). Lanham, MD: Lexington Books.

Makeham, John, \& Hsiau, A-chin. (Eds.) (2005). Cultural, ethnic, and political nationalism in contemporary Taiwan: Bentuhua. New York: Palgrave Macmillan.

Mathews, John A., \& Cho, Dong-Sung. (2000). Tiger technology: The creation of a semiconductor industry in East Asia. Cambridge: Cambridge University Press.

Mendel, Douglas. (1970). The politics of formosan nationalism. Berkeley: University of California Press.

Moody, Peter R. (1992). Political change on Taiwan: A study of ruling party adaptability. New York: Praeger:

Murayama, Hiroshi. (2017, April 17). South Korea, Taiwan Face High-Income Trap. Nikkei Asian Review. Retrieved from www.asia.nikkei.com

National Development Council (NDC). (2016). Taiwan Statistical Data Book, 2016. Taipei: National Development Council.

Naughton, Barry. (Ed.) (1997). The China circle: Economics and electronics in the PRC, Taiwan, and Hong Kong. Washington, DC: Brookings.

O'Donnell, Guillermo, Schmitter, Phillipe C., \& Whitehead, Laurence. (Eds.) (1986). Transitions from authoritarian rule: Prospects for democracy. Baltimore: Johns Hopkins University Press.

Olson, Mancur, Jr. (1982). The rise and fall of nations: economic growth, stagflation and social rigidities. New Haven: Yale University Press.

Organization for Economic Co-operation and Development (OECD). (2012). Divided we stand: Why inequality keeps rising. Paris: OECD.

Prebisch, Raul. (1950). The Economic Development of Latin America and its principal problems. New York: Free Press.

Rigger, Shelley. (1999). Politics in Taiwan: Voting for democracy. London: Routledge.

Rigger, Shelley. (2004). Taiwan in 2003: Plenty of clouds, few silver linings. Asian Survey, 44(1), 182-7.

Rigger, Shelley. (2010). Ma's puzzling midterm Malaise. In Brookings Northeast Asian Commentary, 37, Washington, DC: Brookings Institution. Retrieved from www.brookings.edu

Rostow, W. W. (1960). The stages of economic growth: A non-communist manifesto. Cambridge: Cambridge University Press.

Shen, Shiau-chi, \& Wu, Nei-the. (2008). Ethnic and civil nationalisms: Two roads toward the formation of a Taiwanese Nation. In Peter C. Y. Chow (Ed.), The "One China" Dilemma (pp. 117-43). New York: Palgrave Macmillan.

Small and Medium Enterprises Administration (SMEA). Ministry of Economic Affairs. (2008). 2008 White Paper on SMEs in Taiwan. Taipei: Ministry of Economic Affairs.

Sutter, Robert G. (1988). Taiwan: Entering the 21st century. Lanham, MD: University Press of America.

Taiwan's 2016 Election and Democratization Study (TEDS). (2016). Mucha, TW: Election Study Center, National Chengchi University.

Tan, Alexander C. (2008). From state entrepreneurs to political entrepreneurs: Democratization and the politics of financial liberalization in Taiwan. In Philip Paolino \& James Meernik (Eds.), Democratization in Taiwan: Challenges in transformation (pp. 153-66). Burlington, VT: Ashgate.

Tan, Alexander C. (2009). The politics of financial reform in Taiwan: Actors, institutions, and the changing state. Asian Affairs: An American Review, 36(4), 201-12.

Tan, Alexander C. (2014). The organisational learning of the Kuomintang in Democratic Taiwan. In A. Butler (Ed.), Remaking of the ANC: Party change in South Africa and the global South (pp. 14-28). Auckland Park, South Africa: Jacana Media.

Tien, Hung-mao. (Ed.) (1996). Taiwan's electoral politics and democratic transition: Riding the third wave. Armonk, NY: M.E. Sharpe.

Tien, Hung-Mao, \& Tung, Chen-Yuan. (2011). Taiwan in 2010: Mapping for a new political landscape and economic outlook. Asian Survey, 51(1), 76-84. 
Vernon, Raymond. (1966). International investment and international trade in the product cycle. Quarterly Journal of Economics, 80(2), 190-207.

Wachman, Alan M. (1994). Taiwan: National identity and democratization. Armonk, NY: M.E. Sharpe.

Wade, Robert. (1990). Governing the market: Economic theory and the role of government in East Asian industrialization. Princeton: Princeton University Press.

Wang, T. Y. (2000). One China, One Taiwan: An analysis of the democratic progressive party's China policy. In W. C. Lee (Ed.), Taiwan in perspective (pp. 159-82). Leiden: Brill.

3 Wang, T. Y., \& Cheng, Su-Feng. (2017, Month). Generation and identity in Taiwan: change and continuity. Paper presented at the Annual Meeting of the American Political, San Francisco, CA.

Winckler, Edwin A. (1984). Institutionalization and participation on Taiwan: From hard to soft authoritarianism? China Quarterly, 99, 481-99.

Wong, Joseph. (2004). Healthy democracies: Welfare politics in Taiwan and South Korea. Ithaca: Cornell University Press.

Wong, Joseph. (2010). From imitator to innovator: The political economy of industrial upgrading in the 21st century. In Wei-chin Lee (Ed.), Taiwan's politics in the 21st century: Changes and challenges (pp. 131-56). London: World Scientific Press.

$\mathrm{Wu}$, Jaushieh Joseph. (1995). Taiwan's democratization: Forces behind the new momentum. Hong Kong: Oxford University Press.

Wu, Yu-shan. (2011). Strategic triangle, change of guard, and Ma's new course. In Cal Clark (Ed.), The changing dynamics of relations among China, Taiwan, and the United States (pp. 30-61). Cambridge: Cambridge Scholars Publishing.

$4 \mathrm{Wu}$, Rong-I, \& Huang, Chung-Che. (2003, Month). Entrepreneurship in Taiwan: Turning point to restart. Paper presented at the US-Japan Dialogue on Entrepreneurship in Asia, Tokyo. 